Open Access

\title{
Comparative ileal amino acid digestibility and growth performance in growing pigs fed different level of canola meal
}

\author{
Kwangyeol Kim, Akshat Goel, Suhyup Lee, Yohan Choi and Byung-Jo Chae*
}

\begin{abstract}
The digestibility of different vegetable protein sources were investigated and the effects of supplementing canola meal (CM) as partial inclusions were studied in growing pigs, to determine the performance parameters and its economic importance. In Exp. 1, four pigs (average initial BW $=15.4 \pm 0.35 \mathrm{~kg}$, 5 weeks of age) fitted with simple T-cannula at terminal ileum, were fed four diets following repeated $4 \times 4$ Latin square design having adoption period of 7 days. Diet 1 was Nitrogen free diet containing corn starch. Diets 2, 3, and 4 were the basal diet supplemented with soybean meal (SBM), rapeseed meal (RSM), and domestic CM respectively. The AID of crude protein was decrease in RSM in comparison to SBM supplementation. The AID of Dietary indispensable amino acids (DIAA) such as Lys, Meth, Pha, and dispensable amino acid Ala, Pro, Asp were decreased $(P<0.05)$ in RSM supplemented diets. The SID of DIAA does not differ but the SID of Asp was higher $(P<0.05)$ in RSM and CM diets while SID of Pro was lower $(P<0.05)$ in RSM in comparison to SBM supplemented diets. In Exp. 2, 192 growing pigs (average initial BW $24.76 \pm 2.55 \mathrm{~kg}$ ) were randomly allotted to four dietary treatments with increasing levels of CM i.e. 0, 3.75, 7.50, and $11.25 \%$ respectively. Diets were fed in meal form for 35 days. Increasing $C M$ levels in diets had no effects $(P>0.05)$ on growth performance and apparent total tract digestibility (ATTD) of nutrients and energy. Total weight gain, total feed intake, and feed cost per $\mathrm{kg}$ weight gain were not affected by increasing levels of CM in diets but total feed cost (TFC) per pigs was linearly reduced (26.463 to 25.674; P < 0.05). Broadly, the AID, and SID of amino acid was reduced in RSM but was not effected in CM in comparison to SBM supplemented pigs. Moreover, increasing levels of CM in pigs diet had no effect on the ATTD and performance but TFC per pig was reduced. Thus CM inclusion of up to $11.25 \%$ in diets can be used for reducing the production cost in growing pigs without any negative effect.
\end{abstract}

Keywords: Protein source, Canola meal, Digestibility, Performance, Economic importance, Weanling-growing pigs

\section{Background}

Cost of pork production is mainly dependent on feed and accounts for almost $70 \%$ of the total cost $[1,2]$. Consistent increase in the price of soybean in the last few years has substantially increased the feed cost $[3,4]$. To overcome this issue, other cheap protein sources are being investigated, that can be used as a substitute of soybean but their selection and optimization is necessary. Few of the most common replacement are rapeseed and canola. Rapeseed meal (RSM) is an economical dietary protein source that acts as a second most widely traded protein ingredient for world protein meal

\footnotetext{
* Correspondence: bjchae@kangwon.ac.kr

Department of Animal Resources Science, College of Animal Life Sciences, Kangwon National University, Chuncheon 200-701, Republic of Korea
}

production [5]. Moreover canola is the product of the genetic modifications of rapeseed and sometimes also known as double low variety [6]. The RSM contains about $40 \%$ crude protein (on DM basis) and about similar or even better amino acids (AA) contents, but its nutrient value depends on the kind of seed, cultural environment, and processing methods [7, 8]. Similarly canola meal $(\mathrm{CM})$ is also famous for its rich protein content and AA profile [9]. Being a residual product of oil extraction process and its easy availability due to increasing use in the biofuel industry, these products are becoming popular alternative protein source for swine production. However high erucic acid and glucosinolates content is the major limiting factor with rapeseed meal that causes change in the thyroid tissue, and inclusion at 
high levels in diets for long periods may affect growingfinishing performance and thyroid hypertrophy $[10,11]$. Drawback with canola meal is its higher level of fiber content that decreases its digestibility [9]. To get the optimum growth, it is important to design the diets on the bases of digestibility i.e. apparent ileal digestibility (AID) and standardized ileal digestibility (SID). Moreover, to make the diets economical without having any negative effect on the performance, it is important to consider the inclusion levels of ingredients in diets. To select the best economical protein source according to their digestibility and to optimize its concentration in the feed of growing pigs, the present research was conducted with RSM and CM for partially substituting it with SBM in growing pigs.

In order to prepare the economical feed composition with optimum performance, the current study was conducted with three different protein supplemented diets i.e. SBM, RSM, and CM. Apparent ileal digestibility (AID) and standardized ileal digestibility (SID) were studied to compare the AA digestibility. Further, the most digestible protein source was further supplemented as inclusions at different concentration in the growing pigs' diet to determine its effects on performance and economic viability.

\section{Methods}

Two experiments were designed and conducted on weanling and growing pigs (Landrace $\times$ Yorkshire $\times$ Duroc) at the facility of Kangwon National University Farm Chuncheon Republic of Korea to study the effect of different protein diets and graded level of CM inclusions on AID, SID of AA, performance, and its economic efficiency in weanling and growing pigs. Both experiments were approved (approval number: KW-141111-2) and swine were cared according to the guidelines of the Institutional Animal Care and Use Committee of Kangwon National University, Chuncheon, Republic of Korea.

\section{Digestibility trial}

After one day of fasting, four weanling pigs, average initial BW $15.4 \pm 0.35 \mathrm{~kg}$, were fitted with a simple Tcannula at the terminal ileum according to the method suggested by Walker et al. [12]. Semi-purified diets were formulated with each protein sources to be tested, i.e. with $\mathrm{N}$-free diet, SBM, RSM, and CM respectively (Table 1). N-free diet was used to study the basal endogenous losses. These diets were fed according to a repeated $4 \times 4$ Latin square design. Vitamins and minerals were supplemented to meet or exceed NRC [13], standards for pigs. All diets contained $0.25 \%$ chromic oxide as the digestibility marker. Each pig was fed 900 gm of feed in three times a day. Each treatment diets were fed for 7 days duration followed by 3 days collection of digesta samples. Second treatment was conducted after
7 days adoption period. Similar routine was followed until all the pigs received all the treatments. The collected samples were immediately frozen at $-80{ }^{\circ} \mathrm{C}$, freeze dried (Samwon Inc., Korea), ground in a $1 \mathrm{~mm}$-mesh Wiley Mill, and stored in a refrigerator until analysis.

Proximate analyses were done by following the methods of AOAC [14]. Gross energy was measured by using bomb calorimeter (Model 1261, Parr Instrument Co., Molin, IL), and chromium with an automated spectrophotometer (Shimadzu, Japan) following the methods of Fenton and Fenton [15], respectively. After the acid hydrolysis in $6 \mathrm{~N} \mathrm{HCL}$ at $105{ }^{\circ} \mathrm{C}$ for $24 \mathrm{~h}$, concentrations of AA were analyzed using a HPLC (Waters 486, USA). Analysis of sulfur containing AA was done after cold performic acid oxidation overnight with subsequent hydrolysis as suggested by Moore [16].

\section{Performance trial}

Total of 192 pigs (Landrace $\times$ Yorkshire $\times$ Duroc) with an average initial body eight (BW) $24.76 \pm 2.55 \mathrm{~kg}$ at 8 week of age were used in a 35-days growth assay. The pigs were allotted to four treatments composed of four pens in each treatment with twelve pigs in each pen. Each $2.8 \times 5 \mathrm{~m}$ pen was equipped with a self-feeder and nipple waterer to allow ad libitum consumption of feed and water. The animals were weighed and feed intake was also determined. The average final BW of the pigs was $49.31 \mathrm{~kg}$. The dietary treatments included a basal diet supplemented with $0,3.75,7.50$, and $11.25 \% \mathrm{CM}$ substrate respectively. Diets for experiment were formulated to contain 3,350 (kcal/ $/ \mathrm{kg}) \mathrm{ME}, 18 \% \mathrm{CP}$ and $0.98 \%$ lysine. Vitamins and minerals were supplemented in all diets and all diets met or exceeded the estimated nutrient requirements suggested for growing pigs by the National Research Council [13].

The pigs were weighed individually and feed consumption of each pen was measured at the end of the experiments. Growth performance in terms of average daily gain (ADG), average daily feed intake (ADFI) and F:G was calculated during the feeding trial. The apparent total tract digestibility (ATTD) of energy and nutrients were evaluated using $0.25 \%$ chromic oxide (an inert indigestible indicator) in each diet from d 28 to d 35 of each experiment and ATTD of DM, GE, and CP were determined by collecting fecal grab samples during last 4 days from the floor of each pen. Pooled fecal samples within pan were then dried in a forced air drying oven at $60{ }^{\circ} \mathrm{C}$ for $72 \mathrm{~h}$, and ground in a Wiley mill (Thomas Model 4 Wiley Mill, Thomas Scientific, Swedesboro, NJ) using a 1-mm screen and used for chemical analysis.

Each sample was analyzed in triplicate for DM (Method 930.15), CP (Method 990.03), ash (Method 942.05), Ca, and P (Method 985.01) according to the methods of AOAC [14]. Gross energy of diets and 
Table 1 Formula and chemical composition of experimental diets for ileal digestibility trials

\begin{tabular}{|c|c|c|c|c|}
\hline Item & $\mathrm{N}$-free & Soybean meal & Rapeseed meal & Canola meal \\
\hline \multicolumn{5}{|l|}{ Ingredients (\%) } \\
\hline Corn starch & 56.50 & 44.79 & 32.34 & 37.94 \\
\hline Soybean meal (44 \%) & - & 52.24 & - & - \\
\hline Rapeseed meal (35 \%) & - & - & 65.57 & - \\
\hline Canola meal (38 \%) & - & - & - & 59.78 \\
\hline Sucrose & 20.00 & - & - & - \\
\hline Glucose & 20.00 & - & - & - \\
\hline Choline chloride (50 \%) & 0.05 & 0.05 & 0.05 & 0.05 \\
\hline $\mathrm{TCP}$ & 1.68 & 1.13 & 0.65 & 0.74 \\
\hline Limestone & 0.62 & 0.64 & 0.24 & 0.34 \\
\hline Salt & 0.30 & 0.30 & 0.30 & 0.30 \\
\hline Mineral premix ${ }^{1}$ & 0.30 & 0.30 & 0.30 & 0.30 \\
\hline Vitamin premix ${ }^{2}$ & 0.30 & 0.30 & 0.30 & 0.30 \\
\hline Chromic oxide & 0.25 & 0.25 & 0.25 & 0.25 \\
\hline Total & 100.00 & 100.00 & 100.00 & 100.00 \\
\hline \multicolumn{5}{|l|}{ Chemical composition (\%) } \\
\hline ME (kcal/kg) & 3,509 & 3,391 & 2,904 & 3,125 \\
\hline$C P$ & - & 23.00 & 23.00 & 23.00 \\
\hline Calcium & 0.70 & 0.70 & 0.70 & 0.70 \\
\hline Available phosphorus & 0.32 & 0.32 & 0.32 & 0.32 \\
\hline Lysine & - & 1.44 & 1.31 & 1.18 \\
\hline Met + Cys & - & 0.66 & 1.08 & 0.76 \\
\hline
\end{tabular}

excreta were measured using a bomb calorimeter (Model 1261, Parr Instrument Co., Molin, IL), while chromium concentrations were determined with an automated spectrophotometer (Shimadzu, Japan) according to the procedure described by Fenton and Fenton [15].

Calculation of feed cost (FC) was based on the price of ingredients. Feed cost per kg body weight gain (FCG) and total feed cost (TFC) was calculated as follows:

$$
\begin{aligned}
\mathrm{FCG} & =\mathrm{TFI} \times \mathrm{FC} / \mathrm{TWG} \\
\mathrm{TFC} & =\mathrm{FC} \times \mathrm{TFI}
\end{aligned}
$$

Where, TFI $=$ total feed intake and FC $=$ feed cost TWG = total weight gain per pig $(\mathrm{kg})$.

\section{Statistical analyses}

Data collected were subjected to statistical analysis using the General Linear Model (GLM). Procedure of SAS [17] was used as complete randomized block design. Orthogonal polynomials were used to evaluate linear and quadratic effects of dietary domestic CM supplementation. The treatments were the main effects. The pens were the experimental units for all analysis but for ileal digestibility each pig was the experimental unit while probability values of $\leq 0.05$ were considered significant.

\section{Results \\ Digestibility trial}

The pigs remained healthy and consumed their feed daily throughout the experiment. No symptoms of disease were seen in any of the pig throughout the experiment.

The chemical composition of the diets is presented in Table 1. Three different protein sources were used in this experiment and one nitrogen free diet was used to measure basal endogenous losses. The level of CP was $23 \%$ and was kept constant in all the three protein source containing diets. Proximate analysis (Table 2) revealed that RSM had lower CP values in comparison to its counterparts. Similarly total mean and sub mean values of AA were also lower in RSM.

The AID of CP and AA of the experimental diets are presented in Table 3. Few of the AA and CP has shown significant responses $(\mathrm{P}<0.05)$ in the AID of different protein source supplemented diets. The AID of CP was 
Table 2 Proximate and amino acid composition of the protein sources used for ileal digestibility

\begin{tabular}{llll}
\hline tem (\%) & Soybean meal & Rapeseed meal & Canola meal \\
\hline DM & 86.33 & 87.51 & 88.63 \\
CP & 44.96 & 34.22 & 37.77 \\
Ash & 4.95 & 6.52 & 6.29 \\
CF & 5.60 & 8.54 & 9.50 \\
Ca & 0.40 & 1.15 & 0.66 \\
P & 0.42 & 0.76 & 1.03 \\
NDF & 12.06 & 22.29 & 25.06 \\
ADF & 8.30 & 14.19 & 16.18
\end{tabular}

Amino acid

Dietary indispensable amino acids

\begin{tabular}{llll} 
Arginine & 3.27 & 2.16 & 2.13 \\
Histidine & 1.19 & 0.91 & 0.97 \\
Isoleucine & 2.04 & 1.25 & 1.36 \\
Leucine & 3.47 & 2.27 & 2.51 \\
Lysine & 2.83 & 1.57 & 2.09 \\
Methionine & 0.61 & 0.65 & 0.74 \\
Phenylalanine & 2.34 & 1.36 & 1.44 \\
Threonine & 1.83 & 1.40 & 1.58 \\
Tryptophan & 0.55 & 0.33 & 0.37 \\
Valine & 2.10 & 1.57 & 1.72 \\
Sub-mean & 20.23 & 13.47 & 14.91 \\
Dietary dispensable & & & \\
amino acids & & & \\
Alanine & 1.95 & 1.40 & 1.57 \\
Aspartic acid & 5.31 & 2.21 & 2.53 \\
Cystine & 0.64 & 0.88 & 0.91 \\
Glutamic acid & 8.47 & 6.17 & 6.34 \\
Glycine & 1.94 & 1.70 & 1.80 \\
Proline & 2.28 & 2.20 & 2.29 \\
Serine & 2.37 & 1.42 & 1.58 \\
Tyrosine & 1.51 & 0.87 & 0.95 \\
Sub-mean & 24.47 & 16.85 & 17.97 \\
Total-mean & 44.70 & 30.32 & \\
\hline & & & \\
\hline
\end{tabular}

lower in RSM but does not differ in CM in comparison to SBM. Amino acid digestibility values were lower in diets supplemented with RSM for DIAA (Lys, Meth and $\mathrm{Pla}$ ), and DDAA (Ala, Asp, and Pro) in comparison to SBM.

The SID of AA for the experimental diets of different protein sources is presented in Table 4. The SID of DIAA does not differ in the dietary treatments but the SID of DDAA like Asp was higher $(\mathrm{P}<0.05)$ in RSM and CM diets while SID of Pro was lower $(\mathrm{P}<0.05)$ in RSM in comparison to SBM supplemented group.
Table 3 Apparent ileal digestibility of protein sources in pigs

\begin{tabular}{|c|c|c|c|c|c|}
\hline Item (\%) & $\begin{array}{l}\text { Soybean } \\
\text { meal }\end{array}$ & $\begin{array}{l}\text { Rapeseed } \\
\text { meal }\end{array}$ & $\begin{array}{l}\text { Canola } \\
\text { meal }\end{array}$ & $\mathrm{SEM}^{1}$ & $p$-value \\
\hline$\overline{\mathrm{CP}}$ & $71.46^{\mathrm{a}}$ & $68.10^{b}$ & $70.51^{\mathrm{ab}}$ & 0.98 & 0.015 \\
\hline \multicolumn{6}{|c|}{$\begin{array}{l}\text { Dietary indispensable } \\
\text { amino acids }\end{array}$} \\
\hline Arginine & 81.50 & 80.28 & 83.53 & 1.24 & 0.087 \\
\hline Histidine & 79.58 & 77.02 & 78.10 & 1.10 & 0.167 \\
\hline Isoleucine & 80.68 & 76.62 & 78.04 & 1.48 & 0.062 \\
\hline Leucine & 81.09 & 79.77 & 80.12 & 1.06 & 0.622 \\
\hline Lysine & $78.69^{\mathrm{a}}$ & $73.03^{b}$ & $76.46^{\mathrm{ab}}$ & 1.80 & 0.016 \\
\hline Methionine & $80.02^{\mathrm{a}}$ & $76.72^{b}$ & $79.30^{\mathrm{ab}}$ & 1.10 & 0.020 \\
\hline Phenylalanine & $80.73^{a}$ & $77.62^{b}$ & $79.26^{\mathrm{ab}}$ & 1.06 & 0.041 \\
\hline Threonine & 74.05 & 71.99 & 75.12 & 1.18 & 0.075 \\
\hline Tryptophane & 73.04 & 70.35 & 72.61 & 2.64 & 0.713 \\
\hline Valine & 73.16 & 71.64 & 72.46 & 1.26 & 0.665 \\
\hline \multicolumn{6}{|c|}{$\begin{array}{l}\text { Dietary dispensable } \\
\text { amino acids }\end{array}$} \\
\hline Alanine & $72.37^{\mathrm{a}}$ & $69.83^{b}$ & $71.67^{\mathrm{ab}}$ & 0.82 & 0.013 \\
\hline Aspartic acid & $73.80^{\mathrm{a}}$ & $70.57^{b}$ & $71.40^{\mathrm{ab}}$ & 1.14 & 0.039 \\
\hline Cystine & 72.06 & 70.72 & 72.01 & 2.02 & 0.855 \\
\hline Glutamic acid & 80.14 & 77.39 & 79.95 & 1.08 & 0.052 \\
\hline Glycine & 72.81 & 71.50 & 72.27 & 0.84 & 0.491 \\
\hline Proline & $79.26^{\mathrm{a}}$ & $77.11^{b}$ & $78.63^{\mathrm{ab}}$ & 0.74 & 0.040 \\
\hline Serine & 75.57 & 74.06 & 74.10 & 0.86 & 0.297 \\
\hline Tyrosine & 75.77 & 72.83 & 74.02 & 1.58 & 0.348 \\
\hline
\end{tabular}

ab Values with different superscripts of the same row are significantly differ $(p<0.05)$

${ }^{1}$ Standard error of means

\section{Performance trial}

All the diets contained similar CP (18 \%) and ME $(3,350 \mathrm{kcal} / \mathrm{kg})$ with increasing inclusion levels of CM 0 , $3.75,7.50$, and $11.25 \%$ (Table 5). Increasing inclusion of CM from 0 to $11.25 \%$ did not affect BW, ADG, ADFI, and F:G (Table 6) in growing pigs.

Few limiting amino acids were added in the feed for maintaining the amino acid content. The digestibility of nutrients was not effected in increasing CM supplementation and there was no variation $(\mathrm{P}>0.05)$ in $\mathrm{DM}, \mathrm{GE}, \mathrm{CP}$, and Ash (Table 7) content of growing pigs.

There was a linear decrease $(\mathrm{P}<0.05)$ in the total feed cost in the pigs with increasing inclusion of $\mathrm{CM}$ in diets (Table 8). However no difference $(\mathrm{P}>0.05)$ was observed in the FC $(\$ / \mathrm{kg})$, TWG $(\mathrm{kg} / \mathrm{pig})$, TFI $(\mathrm{kg} / \mathrm{pig})$, and FCG (\$/kg wt. gain) of the finishing pigs.

Dietary supplementation of increasing CM levels had no effects $(P>0.05)$ on growth performance and ATTD of nutrients and energy. Total weight gain, total feed intake, and feed cost per kg weight gain were not affected by increasing levels of $\mathrm{CM}$ in diets but total feed cost per pigs was reduced $(\mathrm{P}<0.05)$. 
Table 4 Standardized ileal digestibility of protein sources in pigs

\begin{tabular}{|c|c|c|c|c|c|}
\hline Item (\%) & $\begin{array}{l}\text { Soybean } \\
\text { meal }\end{array}$ & $\begin{array}{l}\text { Rapeseed } \\
\text { meal }\end{array}$ & $\begin{array}{l}\text { Canola } \\
\text { meal }\end{array}$ & SEM $^{1}$ & $p$-value \\
\hline \multicolumn{6}{|c|}{$\begin{array}{l}\text { Dietary indispensable } \\
\text { amino acids }\end{array}$} \\
\hline Arginine & 87.00 & 88.66 & 92.02 & 1.27 & 0.055 \\
\hline Histidine & 89.55 & 90.16 & 90.42 & 1.22 & 0.877 \\
\hline Isoleucine & 89.15 & 90.54 & 90.82 & 2.35 & 0.867 \\
\hline Leucine & 86.59 & 88.23 & 87.77 & 0.82 & 0.380 \\
\hline Lysine & 84.67 & 83.88 & 84.60 & 1.54 & 0.924 \\
\hline Methionine & 87.69 & 83.97 & 85.66 & 1.27 & 0.171 \\
\hline Phenylalanine & 86.57 & 87.74 & 88.81 & 1.02 & 0.343 \\
\hline Threonine & 83.87 & 84.93 & 86.57 & 1.00 & 0.211 \\
\hline Tryptophan & 85.79 & 91.77 & 91.69 & 2.09 & 0.121 \\
\hline Valine & 81.38 & 82.72 & 82.56 & 1.80 & 0.850 \\
\hline \multicolumn{6}{|c|}{$\begin{array}{l}\text { Dietary dispensable } \\
\text { amino acids }\end{array}$} \\
\hline Alanine & 80.48 & 81.22 & 81.82 & 0.86 & 0.567 \\
\hline Aspartic acid & $80.02^{b}$ & $85.65^{\mathrm{a}}$ & $84.56^{\mathrm{a}}$ & 1.30 & 0.031 \\
\hline Cystine & 82.73 & 78.54 & 79.57 & 2.70 & 0.542 \\
\hline Glutamic acid & 83.91 & 82.61 & 85.03 & 0.76 & 0.135 \\
\hline Glycine & 90.05 & 91.32 & 90.97 & 0.95 & 0.632 \\
\hline Proline & $86.35^{\mathrm{a}}$ & $84.52^{b}$ & $85.74^{\mathrm{ab}}$ & 0.43 & 0.038 \\
\hline Serine & 83.16 & 86.82 & 85.56 & 1.12 & 0.116 \\
\hline Tyrosine & 86.01 & 90.74 & 90.40 & 3.15 & 0.520 \\
\hline
\end{tabular}

${ }^{\mathrm{ab}}$ Values with different superscripts of the same row are significantly differ $(p<0.05)$

${ }^{1}$ Standard error of means

\section{Discussion}

Effects of different protein source on digestibility performance in weaning pigs

The inclusion of SBM in pig diets as a protein supply is getting costlier, making researchers to look for better alternatives. Rapeseed meal and canola meal are the first few economical choices after SBM and contribute to almost $12.4 \%$ of the world protein meal production [5]. Rapeseed meal has high crude protein content than soybean meal and contains about $30-40 \%$ crude protein on fed bases and 35.96 to $44.75 \%$ on dry matter basis
Table 5 Ingredient and chemical composition of experimental diets

\begin{tabular}{|c|c|c|c|c|}
\hline \multirow[t]{2}{*}{ Item } & \multicolumn{4}{|c|}{ Canola meal (\%) } \\
\hline & 0 & 3.75 & 7.50 & 11.25 \\
\hline Cost $(\$, \mathrm{~kg})$ & 0.455 & 0.451 & 0.448 & 0.445 \\
\hline \multicolumn{5}{|l|}{ Ingredient (\%) } \\
\hline Corn & 66.54 & 66.42 & 65.72 & 64.81 \\
\hline Soybean meal $(44 \%)^{1}$ & 27.34 & 23.88 & 20.86 & 17.88 \\
\hline Domestic canola meal (37 \%) & 0.00 & 3.75 & 7.50 & 11.25 \\
\hline Animal fat & 2.50 & 2.50 & 2.58 & 2.74 \\
\hline Choline-chloride (50 \%) & 0.08 & 0.08 & 0.08 & 0.08 \\
\hline L-lysine $\mathrm{HCl}(78 \%)$ & 0.31 & 0.33 & 0.34 & 0.35 \\
\hline DL-methionine (99 \%) & 0.09 & 0.07 & 0.06 & 0.04 \\
\hline L-threonine (98.5\%) & 0.07 & 0.07 & 0.07 & 0.07 \\
\hline L-tryptophan (10 \%) & 0.26 & 0.30 & 0.32 & 0.34 \\
\hline TCP & 0.91 & 0.94 & 0.98 & 1.01 \\
\hline Limestone & 1.20 & 0.96 & 0.79 & 0.73 \\
\hline Salt & 0.25 & 0.25 & 0.25 & 0.25 \\
\hline Mineral premix ${ }^{2}$ & 0.20 & 0.20 & 0.20 & 0.20 \\
\hline Vitamin premix ${ }^{3}$ & 0.20 & 0.20 & 0.20 & 0.20 \\
\hline Phytase & 0.05 & 0.05 & 0.05 & 0.05 \\
\hline Total & 100.00 & 100.00 & 100.00 & 100.00 \\
\hline \multicolumn{5}{|l|}{ Chemical composition (\%) } \\
\hline ME (kcal/kg) & 3,350 & 3,350 & 3,350 & 3,350 \\
\hline $\mathrm{CP}$ & 18.00 & 18.00 & 18.00 & 18.00 \\
\hline Calcium & 0.75 & 0.75 & 0.75 & 0.75 \\
\hline Available phosphorus & 0.26 & 0.26 & 0.26 & 0.26 \\
\hline SID lysine & 0.98 & 0.98 & 0.98 & 0.98 \\
\hline SID met + cys & 0.55 & 0.55 & 0.55 & 0.55 \\
\hline SID threonine & 0.59 & 0.59 & 0.59 & 0.59 \\
\hline SID tryptophan & 0.17 & 0.17 & 0.17 & 0.17 \\
\hline
\end{tabular}

${ }^{1}$ Soybean meal was replaced by domestic canola meal (SBM: 687 /kg; CM: $480 \mathrm{~W} / \mathrm{kg}$ )

${ }^{2}$ Supplied per kg diet: $150 \mathrm{mg}$ Fe, $96 \mathrm{mg} \mathrm{Cu}, 72 \mathrm{mg} \mathrm{Zn}, 46.49 \mathrm{mg} \mathrm{Mn}, 0.9 \mathrm{mg}$ I, $0.9 \mathrm{mg} \mathrm{Co}, 0.336 \mathrm{mg} \mathrm{Se}$

${ }^{3}$ Supplied per kg diet: 10,000 IU Vit A, 2,500 IU Vit D3, 50 IU Vit E, $1.5 \mathrm{mg}$ Vit $\mathrm{K} 3,1.5 \mathrm{mg}$ Vit B1, $5 \mathrm{mg}$ Vit B2, $3 \mathrm{mg}$ Vit B6, $0.025 \mathrm{mg}$ Vit B12, $15 \mathrm{mg}$ pantothenic acid, $35 \mathrm{mg}$ niacin, $0.15 \mathrm{mg}$ biotin, $1 \mathrm{mg}$ folic acid

Table 6 Effects of supplementation of canola meal on growth performance in growing pigs

\begin{tabular}{|c|c|c|c|c|c|c|c|}
\hline \multirow[t]{2}{*}{ Item } & \multicolumn{4}{|c|}{ Canola meal (\%) } & \multirow[t]{2}{*}{ SEM $^{1}$} & \multicolumn{2}{|l|}{$p$-value } \\
\hline & 0 & 3.75 & 7.50 & 11.25 & & Linear & Quadratic \\
\hline Initial BW (kg) & 24.44 & 24.37 & 24.33 & 24.32 & 0.14 & 0.572 & 0.879 \\
\hline Final BW (kg) & 49.81 & 49.41 & 49.17 & 48.82 & 0.38 & 0.076 & 0.950 \\
\hline ADG (g) & 725 & 715 & 710 & 700 & 10.24 & 0.102 & 0.996 \\
\hline ADFI (g) & 1,584 & 1,577 & 1,571 & 1,573 & 14.76 & 0.625 & 0.775 \\
\hline$F: G$ & 2.18 & 2.21 & 2.21 & 2.25 & 0.02 & 0.196 & 0.822 \\
\hline
\end{tabular}

\footnotetext{
${ }^{1}$ Standard error of means
} 
Table 7 The effect of different supplemental levels of canola meal on nutrient digestibility in pigs

\begin{tabular}{lllllllll}
\hline Item & \multicolumn{3}{l}{ Canola meal (\%) } & \multicolumn{3}{c}{ SEM $^{1}$} & $p$-value \\
& 0 & 3.75 & 7.50 & 11.25 & & Linear & Quadratic \\
\hline DM & 80.09 & 79.59 & 79.17 & 79.02 & 0.70 & 0.330 & 0.926 \\
GE & 79.67 & 79.41 & 78.93 & 78.06 & 0.81 & 0.183 & 0.718 \\
CP & 73.92 & 73.81 & 73.52 & 73.19 & 0.66 & 0.468 & 0.879 \\
Ash & 40.18 & 38.68 & 38.39 & 38.32 & 0.88 & 0.169 & 0.436 \\
\hline
\end{tabular}

${ }^{1}$ Standard error of means

$[11,18]$. In the present study, proximate analysis revealed (Table 2) similar value of CP (34.22 \%) for RSM, however it was lower in comparison to its counterparts. The level of CP was kept constant (Table 1) in all the three experimental diets containing different protein source. However, RSM supplemented diets had lower AID values of CP in comparison to SBM (Table 3). This is in line with the earlier studies of Li et al. [19] as they reported AID values of $\mathrm{CP}$ and most of the AA were significantly lower in rapeseed meal than soybean meal. This could be due to the lower proximate mean and sub mean values of AA in RSM supplemented diets. The other reasons behind this might be the lower percent of $\mathrm{CP}$ on fed bases or the quality of RSM as the concentration of $\mathrm{CP}$ and AA in canola and rapeseed products varies. Further it depends on many factors such as varieties, environmental factors, seed composition, and amount of residual oil and carbohydrates in the meal $[6,10]$.

The values of AID and SID of DIAA in SBM treatment were in similar range to the recent reports of Upadhaya and Kim [20]. Inclusion of 2 to $10 \%$ canola in cornstarch-based soybean meal diets increases the ileal digestibility of most of the indispensable amino acids [21]. However, in the present study, CM treatment had nearby values of AID (Table 3) and SID (Table 4) of amino acid and did not differ with SBM or RSM supplementations. Lysine is considered the first limiting amino acid in most diets and plays an important role in metabolism [22, 23]. Decrease in the AID of Lys, in RSM inclusion might be due to the direct absorption of Lys by the intestine for protein synthesis and other metabolic processes [24]. Methionine is required for growth and maintenance of body protein [25]. Proline is important for differentiation, multiple biochemical, and physiological processes in cells and serves as a major AA for the synthesis of polyamines that improves growth, development, and morphology of small-intestinal in weanling piglet [26, 27]. In this experiment, AID of Meth, and SID of Pro was significantly decreased in RSM inclusion in comparison to SBM. This could be due to the lower digestion of Meth and Pro in RSM and the limited ability of pigs to synthesize proline [28] that may further affect growth performance.

Consistent decrease in the amino acid digestibility in RSM inclusion in pig's diet might be due to the higher content of fibers that causes poor digestibility, increase endogenous secretions, and decrease hydrolysis and absorption of nutrients [10, 29]. Further, anti-nutritional factors such as glucosinolates could be the other reason that usually affects young pigs the most [30].

\section{Effects of increasing level of canola meal on the performance of growing pigs}

The second experiment was conducted to evaluate the effect of inclusion of different levels of CM on the performance and economic benefits in growing pigs. Canola is a genetically modification of traditional varieties of rapeseeds to obtain low level of anti-nutritional factors such as glucosinolates [6]. Studies conducted on chicken had shown that increasing levels of CM in diets resulted in decreasing the cost of production [31, 32]. However economic benefits in pig are yet to be considered. Previous studies revealed that swine diets should be formulated on the basis of true or standardized amino acid digestibility [33]. Therefore, mixing ratio was created by applying the standardized ileal digestibility (SID) that has shown good efficiency on swine.

Increasing level of CM supplementation of up to 200 $\mathrm{gm} / \mathrm{kg}$ in diets or $25 \%$ inclusion decreases the ATTD of DM and CP in pigs $[34,35]$. However in the current study, the maximum dietary inclusions of CM is $11.25 \%$, that is almost half in comparison to the above study therefore no variation $(\mathrm{P}>0.05)$ was observed in ATTD of DM, CP, and GE (Table 7).

Table 8 Effects of level of supplementation of canola meal on the production cost in pigs

\begin{tabular}{|c|c|c|c|c|c|c|c|}
\hline \multirow[t]{2}{*}{ Item } & \multicolumn{4}{|c|}{ Canola meal (\%) } & \multirow[t]{2}{*}{ SEM $^{1}$} & \multicolumn{2}{|l|}{$p$-value } \\
\hline & 0 & 3.75 & 7.50 & 11.25 & & Linear & Quadratic \\
\hline $\mathrm{FC}(\$ / \mathrm{kg})$ & 0.455 & 0.451 & 0.448 & 0.445 & & & \\
\hline TWG (kg/pig) & 25.37 & 25.04 & 24.84 & 24.50 & 0.36 & 0.102 & 0.997 \\
\hline TFI (kg/pig) & 55.45 & 55.20 & 55.01 & 55.09 & 0.50 & 0.623 & 0.779 \\
\hline TFC (\$/pig) & 26.463 & 26.118 & 25.825 & 25.674 & 0.29 & 0.047 & 0.724 \\
\hline FCG (\$/kg wt. gain) & 1.043 & 1.044 & 1.040 & 1.048 & 0.01 & 0.883 & 0.796 \\
\hline
\end{tabular}

${ }^{1}$ Standard error of means 
The present study was conducted on growing pigs with the maximum of $11.25 \%$ of $\mathrm{CM}$ inclusions in the diets to minimize the effects of antinutritional factors. Dietary inclusion of increasing levels of $\mathrm{CM}$ does not have any effect on TWG, TFI, and FCG per kg weight gain. This is in line with the earlier studies of King et al. [36] as they reported no adverse effects of up to $20 \%$ solvent-extracted canola meal on the performance of pigs. This might be due to the use of glucosinolates below the tolerance limit in diets. In similar type of studies conducted on growing-finishing pigs, other workers suggested even higher level of up to 20 to $30 \%$ dietary supplementation of canola products [37, 38]. However, using $16.2 \%$ canola meal in diets fed to finishing pigs (60 to $120 \mathrm{~kg} \mathrm{BW}$ ) resulted in reduced ADG compared with pigs fed the control diet without canola meal due to the increasing impact of glucosinolates with time [11].

Decrease $(\mathrm{P}<0.05)$ in the price of total feed cost per pigs (Table 8) was observed in current study. This is in accordance with the earlier studies of Seneviratne et al. [39] where they suggested inclusion of canola meal in swine diets reduces the feed costs per unit of BW gain without affecting carcass and fat quality. These are the positive sign for pig growers for using CM in diets without affecting nutrient digestibility and growth performance in pigs.

\section{Conclusions}

We therefore conclude that RSM inclusion in diets had lower digestibility of few amino acid in comparison to SBM but digestibility of CM inclusion in diets of weanling pigs were not affected. Inclusion of up to $11.25 \%$ $\mathrm{CM}$ in diets had no effect on the performance and nutrient digestibility of the growing pigs. However the TFC (\$/pig) was reduced linearly. Thus CM can be used up to $11.25 \%$ for replacing SBM in diets of growing pigs for reducing the feed cost in pig production.

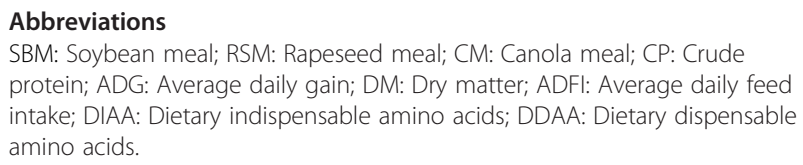

\section{Competing interests}

The authors declare that they have no competing of interests.

\section{Authors' contributions}

BC and KK designed experiment, KK, SL, YC Carried out animal trial, KK, AG, $S L$, and $Y C$ done lab analysis, KK, SL, and $A G$ analyzed data, AG, and BC written manuscript. All authors read and approved the final manuscript.

Received: 25 March 2015 Accepted: 21 May 2015

Published online: 03 June 2015

\section{References}

1. Niemi JK, Sevon-Aimonen ML, Pietola K, Stalder KJ. The value of precision feeding technologies for grow-finish swine. Livest Sci. 2010;129:13-23.
2. Payne LR, Zijlstra RT. Advances in Pork Production, Proc. Banff Pork Semin. In: Ball RO, Zijlstra RT, editors. A guide to application of net energy in swine feed formulation. Alberta, Canada: Univ. Alberta, Edmonton; 2007. p. 159-65.

3. Patience JF. Managing energy intake and costs of grow-finish pigs: Advances in Pork Production. In: Proc. of Banff Pork Seminar, Banff, AB. Edmonton: University of Alberta, Department of Agricultural, Food and Nutritional Science; 2013. p. 29-35.

4. Schmit TM, Verteramo L, Tomek WG. Implications of growing biofuel demands on northeast livestock feed costs. Agric Resour Econ Rev. 2009;38:200-12.

5. Ash M, Dohlman E. Oil, crops situation and outlook yearbook. Electronic outlook report from the economic research service. United States: Department of Agriculture; 2006.

6. Newkirk R. Canola meal, Feed Industries Guide. 4th ed. Winnipeg: Canadian International Grains Institute; 2009.

7. Korelesky J. Improved rapeseed meal or oilseed as a feed for poultry in 9th European Symposium on Poultry Nutrition. Jelenia Gora: Poland; 1993. p. 35-53.

8. Sauer WC, Chicon R, Misir R. Amino acid availability and protein quality of canola and rapeseed meal for pigs and rats. Can J Anim Sci. 1982:54:292-301.

9. Mailer RJ, McFadden A, Ayton J, Redden B. Anti-Nutritional components, fibre, sinapine and glucosinolate content, in Australian canola (Brassica napus L.) meal. J Am Oil Chem Soc. 2008;85:937-44.

10. Bell JM. Factors affecting the nutritional value of canola meal: A review. Can J Anim Sci. 1993;73:679-97.

11. Roth-Maier DA, Bohmer BM, Roth FX. Effects of feeding canola meal and sweet lupin (L.luteus, L.angustifolius) in amino acid balanced diets on growth performance and carcass characteristics of growing-finishing pigs. Anim Res. 2004:53:21-34.

12. Walker WR, Morgan $G L$, Maxwell CV. Ileal cannulation in baby pigs with a simple T-cannula. J Anim Sci. 1986;62:407-11.

13. NRC. Nutrient Requirements of Swine. 11th ed. Washington: Natl. Acad. Press; 2012.

14. AOAC. Official Methods of Analysis of the Association of Official Analytical Chemists International. 18th ed. Gaithersburg: AOAC; 2007.

15. Fenton TW, Fenton M. An improved procedure for the determination of chromic oxide in feed and feces. Can J Anim Sci. 1979;59:631-63.

16. Moore S. On the determination of cystine as cysteric acid. J Biol Sci. 1963;38:235-7.

17. SAS. Software for PC. NC, USA: SAS Institute. Ins, Cart; 2012. Release 9.3.

18. Zhang T, Liu L, Piao XS. Predicting the digestible energy of rapeseed meal from Its chemical composition in growing-finishing pigs. Asian-Aust J Anim Sci. 2012;25:375-81.

19. Li D, Pengbin $X$, Liming G, Shijun F, Canghai $H$. Determination of apparent ileal amino acid digestibility in rapeseed meal and cake processed at different temperatures using the direct and difference method with growing pigs. Arch Tierernahr. 2002;56(5):339-49.

20. Upadhaya SD, Kim $H_{H}$. Ileal digestibility of nutrients and amino acids in unfermented, fermented soybean meal and canola meal for weaning pigs. Anim Sci. 2014. doi:10.1111/asj.12305.

21. Imbeah M, Sauer WC. The effect of dietary level of fat on amino acid digestibility's in soybean meal and canola meal and on rate of passage in growing pigs. Livest Prod Sci. 1991;29:227-39.

22. Zangeronimo MG, Fialho ET, Lima JAF, Girao LVC, Amaral NO, Silveira H. Performance and carcass characteristics of swine from 20 to $50 \mathrm{~kg}$ receiving diets with reduced crude protein and different levels of true digestible lysine. Cienc Rural. 2009;39:1507-13.

23. Stoll B, Burrin D, Henry J, Yu H, Jahoor F, Reeds P. Dietary amino acids are the preferential source of hepatic protein synthesis in piglets. J Nutr. 1998;128:1517-24.

24. Wu GY. Amino acids: metabolism, functions, and nutrition. Amino Acids. 2009;37:1-17.

25. Job TA. Utilization and protein supplementation of cassava for animal feeding and the effect of sulfur source on cyanide detoxification. Nigeria: PhD Thesis University of Ibadan; 1975.

26. Wu G, Bazer FW, Datta S, Johnson GA, Li P, Satterfield MC, et al. Proline metabolism in the conceptus: implications for fetal growth and development. Amino Acids. 2008;35:691-702.

27. Wu G, Bazer FW, Burghardt RC, Johnson GA, Kim SW, Knabe DA, et al. Proline and hydroxyproline metabolism: implications for animal and human nutrition. Amino Acids. 2011;40:1053-63. 
28. Wu G, Knabe DA, Flynn NE, Yan W, Flynn SP. Arginine degradation in developing porcine enterocytes. Am J Physiol Gastrointest Liv Physiol. 1996;271:913-9.

29. Wilfart A, Montagne L, Simmins H, Noblet J, Van Milgen J. Effect of fiber content in the diet on the mean retention time in different segments of the digestive tract in growing pigs. Livest Sci. 2007;109:27-9.

30. Corino C, Baidi A, Bontempo V. Influence of low-glucosinolate rapeseed meal on performance and thyroid hormone status of heavy pigs. Anim Feed Sci Technol. 1991;35:321-31.

31. Nascimento AHD, Gomes PC, Rostagno HS, Albino LFT, Gomes MFM, Runho RC. Use of canola meal in diets for broiler chickens. Rev Bras Zootech. 1998;27(6):1168-76.

32. Naseem MZ, Khan SH, Yousaf M. Effect of feeding various levels of canola meal on the performance of broiler chickens. J Anim PI Sci. 2006;16(3-4):78.

33. Nyachoti CM, De Lange CFM, Schulze H. Estimating endogenous amino acid flows at the terminal ileum and true ileal amino acid digestibilities in feedstuffs for growing pigs using the homoarginine method. J Anim Sci. 1997;75:3206-13.

34. Landero JL, Beltranenaa E, Cervantes M, Morales A, Zijlstra RT. The effect of feeding solvent-extracted canola meal on growth performance and diet nutrient digestibility in weaned pigs. Anim Feed Sci Tech. 2011;170:136-40.

35. Sanjayan N, Heo JM, Nyachoti CM. Nutrient digestibility and growth performance of pigs fed diets with different levels of canola meal from Brassica napus black and Brassica juncea yellow. J Anim Sci. 2014;92:3895-905.

36. King RH, Eason PE, Kerton DK, Dunshea FR. Evaluation of solvent-extracted canola meal for growing pigs and lactating sows. Aust J Agric Res. 2001;52:1033-41.

37. Brand TS, Brandt DA, Cruywagen CW. Utilization of growing-finishing pig diets containing high levels of solvent or expeller oil extracted canola meal. New Zeal J Agr Res. 2001;44:31-5.

38. McDonnell P, O'Shea C, Figat S, O'Doherty JV. Influence of incrementally substituting dietary soya bean meal for rapeseed meal on nutrient digestibility, nitrogen excretion, growth performance and ammonia emission from growing-finishing pigs. Arch Anim Nutr. 2010;65:412-24.

39. Seneviratne RW, Young MG, Beltranena E, Goonewardene LA, Newkirk RW, Zijlstra RT. The nutritional value of expeller-pressed canola meal for grower-finisher pigs. J Anim Sci. 2010;88:2073-83.

\section{Submit your next manuscript to BioMed Central and take full advantage of:}

- Convenient online submission

- Thorough peer review

- No space constraints or color figure charges

- Immediate publication on acceptance

- Inclusion in PubMed, CAS, Scopus and Google Scholar

- Research which is freely available for redistribution 